Jurnal Teknik Komputer AMIK BSI

Volume 7, No.1, Januari 2021

P-ISSN 2442-2436, E-ISSN: 2550-0120

Akreditasi Ristekdikti, No: 36/E/KPT/2019 (Sinta 4)

DOI: $10.31294 /$ jtk.v4i2

\title{
Perancangan Program Administrasi Rawat Jalan Pada Rumah Sakit Ibu Dan Anak Ibnu Sina
}

\author{
Norma Yunita', Muhamad Angga Maulana ${ }^{2}$, Daning Nur Sulistyowati ${ }^{3}$, Maruloh ${ }^{4}$ \\ ${ }^{1,3,4}$ Sekolah Tinggi Manajemen Informatika dan Komputer Nusa Mandiri \\ ee-mail: norma.nyt@nusamandiri.ac.id \\ 3e-mail: daningnur.dgs@nusamandiri.ac.id \\ 4e-mail: maruloh.mru@nusamandiri.ac.id \\ ${ }^{2}$ Universitas Bina Sarana Informatika \\ e-mail: angga816.am@gmail.com

\begin{tabular}{ccc}
\hline Diterima & Direvisi & Disetujui \\
$19-10-2020$ & $02-11-2020$ & $23-01-2020$ \\
\hline
\end{tabular}

\begin{abstract}
Abstrak - Tak dapat dipungkiri teknologi berkembang dengan sangat cepat. Segala kegiatan dalam perusahaan atau instansi sudah banyak yang beralih pada sistem komputerisasi. Tak terkecuali rumah sakit. Dalam memberikan pelayanan kesehatan kepada pasien, rumah sakit dituntut untuk dapat melakukannya dengan cepat, tepat, dan efisien dengan tidak mengurangi standar mutu pelayanan. Penggunaan sistem konvensional menjadikan rumah sakit terhambat dalam pelaksaanaan kegiatan pelayanan. Padahal rumah sakit memiliki kewajiban untuk membuat, melaksanakan, dan menjaga standar mutu pelayanan kesehatan di rumah sakit sebagai acuan dalam melayani pasien. Pada Rumah Sakit Ibu dan Anak Ibnu Sina, dalam pelayanan pasien untuk pendaftaran pasien rawat jalan masih menggunakan sistem konvensional sehingga dibutuhkan peralihan sistem dari konvensional menjadi komputerisasi demi menjaga mutu pelayanan. Adapun sistem yang dibutuhkan, yaitu pendaftaran dan pengelolaan data pasien rawat jalan. Sistem disusun dengan menggunakan metode waterfall sebagai metode pengembangan perangkat lunak dan menerapkan sistem dalam bentuk aplikasi desktop dengan menggunakan bahasa pemrograman Codeigniter 3, PHP 7, dab Bootstrap 4. Diharapkan dengan adanya sistem ini, rumah sakit dapat berjalan lebih baik dan dapat meningkatkan kualitas rumah sakit dalam pelayanan sehingga pasien merasa puas terhadap pelayanan yang diberikan oleh rumah sakit.
\end{abstract}

Kata Kunci: Program, Codeigniter, Waterfall

\begin{abstract}
It is undeniable that technology is developing very fast. All the activities in the company or agency have shifted to computerization. The hospital is no exception. In providing health services to patients, hospitals are required to be able to do it quickly, precisely, and efficiently by not reducing the quality standard of service. The use of conventional systems makes hospitals hampered in the implementation of service activities. Whereas hospitals have an obligation to create, implement and maintain quality standards of health services in hospitals as a reference in serving patients. At the Ibnu Sina Mother and Child Hospital, in the service of patients for outpatient registration they still use the conventional system so that it is necessary to transition the system from conventional to computerized in order to maintain the quality of service. The system needed, namely registration and management of outpatient data. The system is prepared using the waterfall method as a method of software development and implementing the system in the form of a desktop application using the programming language Codeigniter 3, PHP 7, and Bootstrap 4. It is expected that with this system, hospitals can run better and can improve hospital quality in services so that patients feel satisfied with the services provided by the hospital.
\end{abstract}

Keywords: Program, Codeigniter, Waterfall

\section{PENDAHULUAN}

Kesehatan merupakan hal penting yang harus dijaga. Salah satu upaya yang harus diperhatikan adalah menjaga kesehatan yang akan berpengaruh pada aktivitas dan kinerja diri sendiri maupun orang lain.
Pada saat ini banyak orang yang kurang menghiraukan kesehatan mereka karena kesibukannya, akibatnya tempat pelayanan kesehatan seperti rumah sakit menjadi banyak dikunjungi oleh orang yang ingin berobat ( $\mathrm{F}$ et al., 2019). 
Dikarenakan sistem rumah sakit masih berupa metode lama, pasien harus menunggu lama untuk melakukan pendaftaran saat memerlukan perawatan medis, seperti saat antri untuk melakukan check up, pengambilan obat, dan melakukan transaksi pembayaran (Handayani et al., 2020).

Pada Rumah Sakit Ibu dan Anak Ibnu Sina pelayanan yang diberikan masih belum optimal karena masih mengalami kesulitan dalam proses administrasi rawat jalan dikarenakan masih menggunakan sistem pencatatan berupa kertas sebagai medianya. Saat pasien baru atau pasien lama mendaftar, petugas harus mencatat data pasien kedalam buku besar dan mencari data pasien yang kemudian dicocokkan dengan kartu pasien satu per satu pada dokumen yang tersimpan pada rak. Selanjutnya pada saat pemeriksaan, dokter harus mencatat data diagnosa dan resep obat pada kartu rekam medis yang masih menggunakan arsip berupa kertas.

\section{Identifikasi Permasalahan}

Berdasarkan latar belakang masalah, maka penulis menarik permasalahan sebagai berikut :

1. Merancang dan membuat program yang dapat mengelola data pasien, obat, dokter, poliklinik, rekam medis, registrasi serta pembuatan laporan rawat jalan.

2. Program sistem administrasi rawat jalan berbasis web tersebut dirancang dengan menggunakan perangkat lunak sebagai berikut: Sistem Operasi Windows 10, Sublime Text 3, Xampp, PHP, MySQL, dan Google Chrome.

\section{METODOLOGI PENELITIAN}

Adapun metode yang dilakukan dalam penelitian ini diantaranya:

\section{A. Metode Pengumpulan Data}

Metode yang digunakan dalam penelitian ini yaitu:

1. Metode Observasi

Penulis melakukan pengamatan secara langsung pada suatu kegiatan yang sedang dilakukan khususnya bagian rawat jalan Rumah Sakit Ibu dan Anak Ibnu Sina.

\section{Metode Wawancara}

Kegiatan ini berupa tanya jawab serta mencatat penjelasan yang diberikan oleh sumber yang mengetahui masalah tentang administrasi rawat jalan pada Rumah Sakit Ibu dan Anak Ibnu Sina.

\section{Metode Studi Pustaka}

Selain melakukan metode wawancara, penulis juga melakukan penelitian dengan mempelajari sistem mengenai administrasi rawat jalan serta melakukan studi kepustakaan melalui literatur atau referensi yang terdapat di internet.

\section{B. Metode Pengembangan Sistem}

Metode waterfall adalah metode yang digunakan dalam pengembangan sistem ini. Metode waterfall (sequential linear) atau disebut juga alur hidup klasik (classic life cycle) adalah metode terurut yang menyediakan pendekatan alur hidup perangkat lunak dimulai dari analisis, desain, pengkodean, pengujian, dan pendukung (support) (Dermawan \& Hartini, 2017).

\section{Analisis Kebutuhan Perangkat Lunak}

Penulis menganalisa sistem seperti apa yang hendak dibuat berdasarkan hasil wawancara pada pegawai RSIA Ibnu Sina. Analisa mengenai prosedur sistem administrasi rawat jalan dilakukan agar nantinya website yang dihasilkan sesuai dengan kebutuhan dan harapan.

\section{Desain}

Penulis membuat desain antar muka dan desain struktur data berdasarkan kebutuhan yang sudah dianalisa. Penulis mendesain tampilan website yang terdiri dari halaman back end dan mendesain tabeltabel di database. Hal ini dilakukan agar dapat diimplementasikan menjadi program pada tahap pengkodean.

\section{Pembuatan Kode Program}

Pembuatan kode program berdasarkan desain yang telah dibuat diimplementasikan menjadi program utuh agar dapat dimanfaatkan sesuai tujuannya. Adapun bahasa pemrograman yang digunakan, yaitu PHP, CSS dan Javascript.

\section{Pengujian}

Tools yang telah dibuat dalam website perlu diuji untuk memastikan output yang dihasilkan sesuai dengan yang diinginkan dan untuk meminimalisir kesalahan (error). Pengujian ini menggunakan black box testing (pengujian kotak hitam).

\section{Support dan Maintenance}

Penulis melakukan pemeliharaan terhadap program yang telah diterapkan apabila terdapat kesalahan atau perubahan yang tidak terdeteksi pada saat pengujian. Pemeliharaan sistem yang secara rutin dapat meliputi melakukan backup dan update data ataupun penataan ulang database.

\section{HASIL DAN PEMBAHASAN}

Hasil perancangan sistem dan pembahasan dari penelitian ini ditemukan beberapa kebutuhan diantaranya:

\section{Analisis Kebutuhan}

Adapun analisi kebutuhan yang ada berupa analisis kebutuhan pengguna dan analisis kebutuhan sistem.

a. Analisis Kebutuhan Pengguna

Pada website administrasi rawat jalan terdapat dua pengguna, yaitu user dan dokter. Kebutuhan yang dibutuhkan sebagai berikut:

1) Halaman User 
a) User dapat login ke halaman user

b) User dapat mengganti password

c) User dapat mencari data menggunakan kolom search

d) User dapat menambah, mengedit, dan menghapus data pasien

e) User dapat menambah dan menghapus data rekam medis

f) User dapat menambah, mengedit, dan menghapus data dokter

g) User dapat menambah, mengedit, dan menghapus data obat

h) User dapat menambah dan menghapus data resep

i) User dapat menambah dan menghapus data poliklinik

j) User dapat menambah dan menghapus data registrasi

k) User dapat mencetak laporan registrasi rawat jalan

1) User dapat logout

2) Halaman Dokter

a) Dokter dapat dapat login ke halaman dokter

b) Dokter dapat menambah dan menghapus data resep

c) Dokter dapat mengganti password

d) Dokter dapat mencari data menggunakan kolom search

e) Dokter dapat menambah dan menghapus data rekam medis

f) Dokter dapat mencetak laporan registrasi rawat jalan

g) Dokter dapat logout

b. Analisis Kebutuhan Sistem

Adapun kebutuhan sistem pada website perhitungan kenaikan tunjangan bahaya radiasi, antara lain:

1) Memberikan akses untuk login

2) Memberikan layanan untuk mengelola data $u$ ser

3) Memberikan layanan untuk mengelola data rekam medis

4) Memberikan layanan untuk mengelola data pasien

5) Memberikan layanan untuk mengelola data dokter

6) Memberikan layanan untuk mengelola data obat

7) Memberikan layanan untuk mengelola data resep

8) Memberikan layanan untuk mengelola data poliklinik

9) Memberikan layanan untuk mengelola data registrasi

10) Memyediakan layanan ubah password

11) Memberikan layanan mencari data menggunakan kolom search
12) Memberikan laporan registrasi rawat jalan

\section{Rancangan Database}

Basis data (Database) adalah kumpulan dari data, yang dapat digambarkan sebagai aktifitas dari satu atau lebih organisasi yang berelasi (Muharam et al., 2018). Pada tahap rancangan database penulis menggambarkan dalam bentuk ERD dan LRS serta spesifikasi file untuk database yang dibuat.

a. Entity Relationship Diagram (ERD) adalah fakta yang terdiri dari komponen himpunan entitas dan himpunan relasi yang masingmasing dilengkapi dengan atribut-atribut (Hardiyanto et al., 2019).

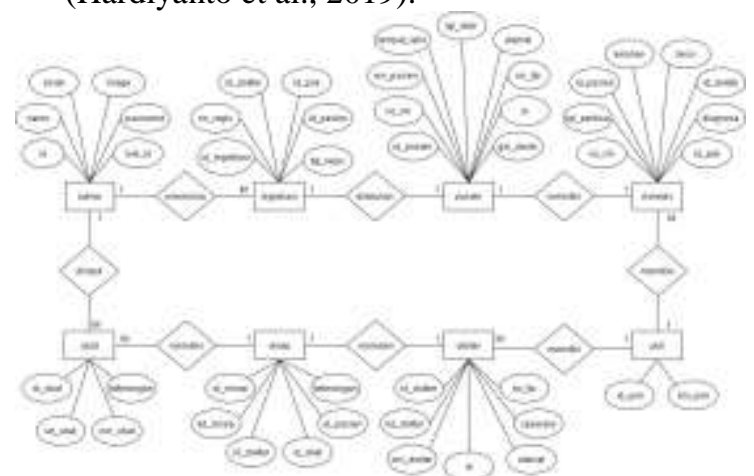

Gambar 1. Entity Relationship Diagram (ERD)

b. Logical Record Structure (LRS) adalah tabeltabel yang terdiri dari struktur record-record yang terbentuk dari hasil relasi antar himpunan entitas (Fridayanthie \& Mahdiati, 2016).

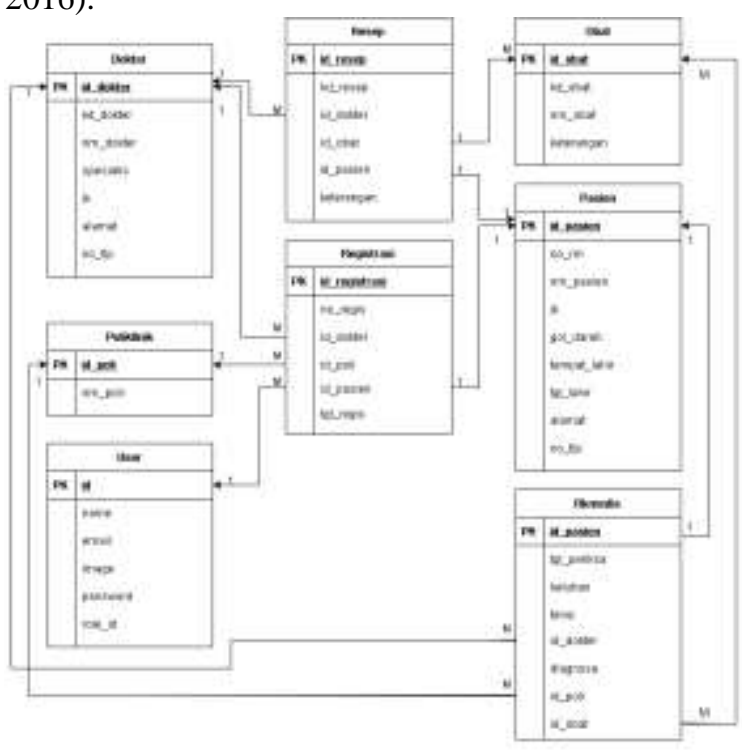

Gambar 2. Logical Record Structure (LRS)

c. Dalam perancangan program administrasi rawat jalan, terdapat 8 (delapan) file basis data yang digunakan, yaitu: 
Tabel 1 Spesifikasi File User

\begin{tabular}{|c|l|c|c|c|l|}
\hline No. & $\begin{array}{l}\text { Elemen } \\
\text { Data }\end{array}$ & Akronim & Tipe & Panjang & Keterangan \\
\hline 1 & Id & Id & Int & 11 & $\begin{array}{l}\text { Primary } \\
\text { Key }\end{array}$ \\
\hline 2 & Name & Name & Varchar & 125 & \\
\hline 3 & Email & Email & Varchar & 30 & \\
\hline 4 & Image & Image & Varchar & 125 & \\
\hline 5 & Password & Password & Varchar & 125 & \\
\hline 6 & Role id & role_id & Int & 11 & \\
\hline
\end{tabular}

Tabel 2 Spesifikasi File Dokter

\begin{tabular}{|c|l|c|c|c|l|}
\hline No. & $\begin{array}{l}\text { Elemen } \\
\text { Data }\end{array}$ & Akronim & Tipe & Panjang & Keterangan \\
\hline 1 & $\begin{array}{l}\text { Id } \\
\text { Dokter }\end{array}$ & id_dokter & Int & 11 & $\begin{array}{l}\text { Primary } \\
\text { Key }\end{array}$ \\
\hline 2 & $\begin{array}{l}\text { Kode } \\
\text { Dokter }\end{array}$ & kd_dokter & Varchar & 125 & \\
\hline 3 & $\begin{array}{l}\text { Nama } \\
\text { Dokter }\end{array}$ & nm_dokter & Varchar & 125 & \\
\hline 4 & Spesialis & spesialis & Enum & 0 & \\
\hline 5 & $\begin{array}{l}\text { Jenis } \\
\text { Kelamin }\end{array}$ & jk & Enum & 0 & \\
\hline 6 & Alamat & alamat & Varchar & 125 & \\
\hline 7 & $\begin{array}{l}\text { No } \\
\text { Telepon }\end{array}$ & no_tlp & Varchar & 20 & \\
\hline
\end{tabular}

Tabel 3 Spesifikasi File Obat

\begin{tabular}{|c|l|c|c|c|l|}
\hline No. & $\begin{array}{c}\text { Elemen } \\
\text { Data }\end{array}$ & Akronim & Tipe & Panjang & Keterangan \\
\hline 1 & Id Obat & id_obat & Int & 11 & $\begin{array}{l}\text { Primary } \\
\text { Key }\end{array}$ \\
\hline 2 & Kode Obat & kd_obat & Int & 11 & \\
\hline 3 & Nama Obat & nm_obat & Varchar & 125 & \\
\hline 4 & Keterangan & keterangan & Varchar & 125 & \\
\hline
\end{tabular}

Tabel 4 Spesifikasi File Pasien

\begin{tabular}{|c|l|c|c|c|l|}
\hline No & $\begin{array}{c}\text { Elemen } \\
\text { Data }\end{array}$ & Akronim & Tipe & Panjang & Keterangan \\
\hline 1 & Id Pasien & id_pasien & Int & 11 & $\begin{array}{l}\text { Primary } \\
\text { Key }\end{array}$ \\
\hline 2 & $\begin{array}{l}\text { No } \\
\text { Rekam } \\
\text { Medis }\end{array}$ & no_rm & Varchar & 20 & \\
\hline 3 & $\begin{array}{l}\text { Nama } \\
\text { Pasien }\end{array}$ & nm_pasien & Varchar & 50 & \\
\hline 4 & $\begin{array}{l}\text { Jenis } \\
\text { Kelamin }\end{array}$ & jk & Enum & 0 & \\
\hline 5 & $\begin{array}{l}\text { Golongan } \\
\text { Darah }\end{array}$ & gol_darah & Enum & 0 & \\
\hline 6 & $\begin{array}{l}\text { Tempat } \\
\text { Lahir }\end{array}$ & tempat_lahir & Varchar & 125 & \\
\hline 7 & $\begin{array}{l}\text { Tanggal } \\
\text { Lahir }\end{array}$ & tgl_lahir & Date & 0 & \\
\hline 8 & Alamat & alamat & Text & 0 & \\
\hline 9 & $\begin{array}{l}\text { No } \\
\text { Telepon }\end{array}$ & no_tlp & Varchar & 20 & \\
\hline
\end{tabular}

Tabel 5 Spesifikasi File Poliklinik

\begin{tabular}{|c|l|c|c|c|l|}
\hline No. & $\begin{array}{l}\text { Elemen } \\
\text { Data }\end{array}$ & Akronim & Tipe & Panjang & Keterangan \\
\hline 1 & Id Poli & id_poli & Int & 11 & $\begin{array}{l}\text { Primary } \\
\text { Key }\end{array}$ \\
\hline 2 & $\begin{array}{l}\text { Nama } \\
\text { Poli }\end{array}$ & nm_poli & Varchar & 125 & \\
\hline
\end{tabular}

Tabel 6 Spesifikasi File Registrasi

\begin{tabular}{|l|l|c|c|c|c|}
\hline No. & $\begin{array}{l}\text { Elemen } \\
\text { Data }\end{array}$ & Akronim & Tipe & Panjang & Keterangan \\
\hline
\end{tabular}

\begin{tabular}{|c|l|c|c|c|l|}
\hline 1 & $\begin{array}{l}\text { Id } \\
\text { Registrasi }\end{array}$ & id_registrasi & Int & 11 & $\begin{array}{l}\text { Primary } \\
\text { Key }\end{array}$ \\
\hline 2 & No Regis & no_regis & Varchar & 125 & \\
\hline 3 & Id Dokter & id_dokter & Int & 11 & Foreign Key \\
\hline 4 & Id Poli & id_poli & Int & 11 & Foreign Key \\
\hline 5 & Id Pasien & id_pasien & Int & 11 & Foreign Key \\
\hline 6 & $\begin{array}{l}\text { Tanggal } \\
\text { Regis }\end{array}$ & tgl_regis & Date & 0 & \\
\hline
\end{tabular}

Tabel 7 Spesifikasi File Resep

\begin{tabular}{|c|l|c|c|c|l|}
\hline No. & $\begin{array}{c}\text { Elemen } \\
\text { Data }\end{array}$ & Akronim & Tipe & Panjang & Keterangan \\
\hline 1 & Id Resep & id_resep & Int & 11 & $\begin{array}{l}\text { Primary } \\
\text { Key }\end{array}$ \\
\hline 2 & $\begin{array}{l}\text { Kode } \\
\text { Resep }\end{array}$ & kd_resep & Varchar & 125 & \\
\hline 3 & Id Dokter & id_dokter & Int & 11 & Foreign Key \\
\hline 4 & Id Obat & id_obat & Int & 11 & Foreign Key \\
\hline 5 & Id Pasien & id_pasien & Int & 11 & Foreign Key \\
\hline 6 & Keterangan & keterangan & Text & 0 & \\
\hline
\end{tabular}

Tabel 8 Spesifikasi File Rekam Medis

\begin{tabular}{|c|c|c|c|c|l|}
\hline No & $\begin{array}{c}\text { Elemen } \\
\text { Data }\end{array}$ & Akronim & Tipe & Panjang & Keterangan \\
\hline 1 & Id Pasien & id_pasien & Int & 11 & $\begin{array}{l}\text { Primary } \\
\text { Key }\end{array}$ \\
\hline 2 & $\begin{array}{l}\text { Tanggal } \\
\text { Periksa }\end{array}$ & tgl_periksa & date & 0 & \\
\hline 3 & Keluhan & keluhan & Varchar & 125 & \\
\hline 4 & Tensi & tensi & Varchar & 125 & \\
\hline 5 & $\begin{array}{l}\text { Id } \\
\text { Dokter }\end{array}$ & id_dokter & Int & 11 & Foreign Key \\
\hline 6 & Diagnosa & diagnosa & Varchar & 125 & \\
\hline 7 & Id Poli & id_poli & Int & 11 & Foreign Key \\
\hline 8 & Id Obat & id_obat & Int & 11 & Foreign Key \\
\hline
\end{tabular}

3. Implementasi

a. Halaman Login

User dan dokter harus melakukan login terlebih dahulu untuk dapat mengakses halamannya masing-masing. Jika login berhasil, maka halaman dashboard dari masing-masing level akan ditampilkan.

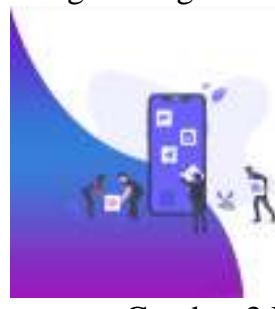

Gambar 3 Halaman Login

b. Halaman Dashboard User

Setelah user berhasil login, sistem akan menampilkan halaman dashboard dimana terdapat menu Data Master, Jenis Poli, Registrasi Rawat Jalan, Rekam Medis, Resep Obat, Informasi, Daftar Ruang Rawat Inap, 
dan Jadwal Praktek.

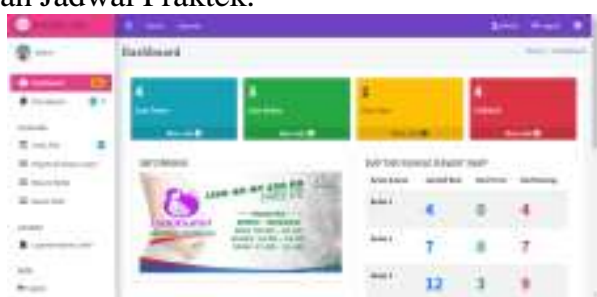

Gambar 4 Halaman Dashboard User

c. Halaman Dashboard Dokter

Setelah dokter berhasil login, sistem akan menampilkan halaman dashboard dimana terdapat menu Data Master, Rekam Medis, dan Resep Obat.

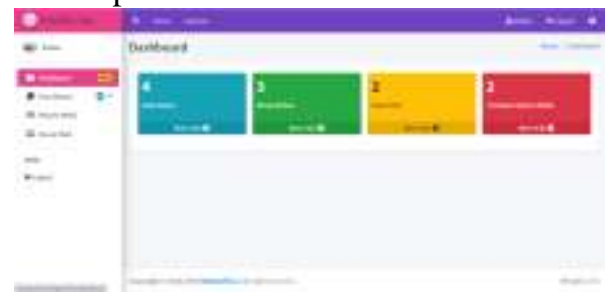

Gambar 5 Halaman Dashboard Dokter

d. Halaman Data Pasien

Halaman ini menampilkan keseluruhan data pasien rawat jalan. User dapat mengelola data pasien seperti menambahkan, mengedit, dan menghapus data.

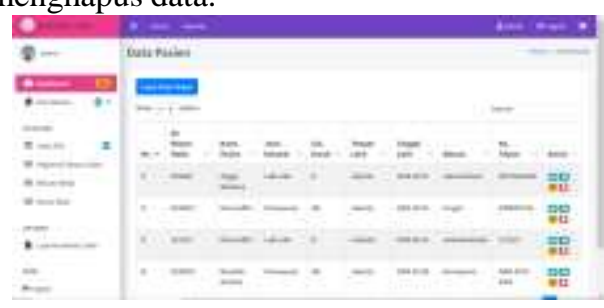

Gambar 6 Data Pasien

e. Halaman Data Registrasi Rawat Jalan

Halaman ini menampilkan keseluruhan form dan data keseluruhan registrasi rawat jalan yang terdapat pada RSIA Ibnu Sina. User dapat mengelola data registrasi rawat jalan seperti menambahkan dan menghapus data.

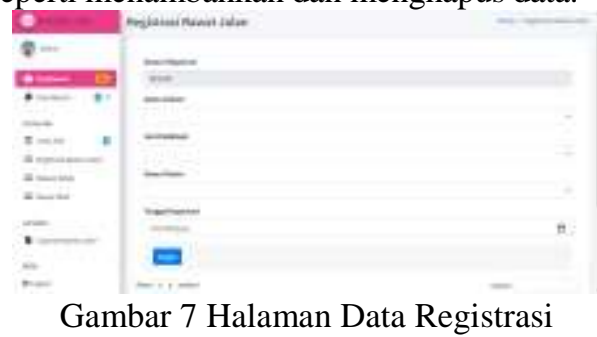

f. Halaman Form Rekam Medis

Halaman ini menampilkan keseluruhan form dan data keseluruhan rekam medis pasien pada RSIA Ibnu Sina. User dapat mengelola data rekam medis seperti menambahkan dan menghapus data.

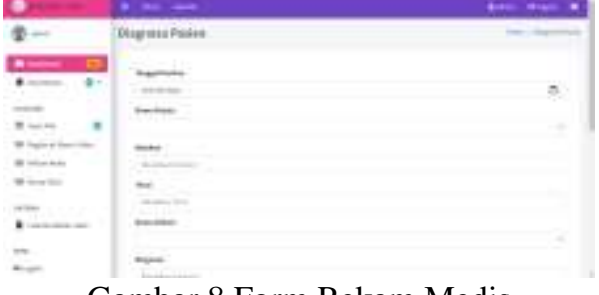

Gambar 8 Form Rekam Medis

g. Halaman Data Laporan

Halaman ini menampilkan data hasil sortir laporan berdasarkan tanggal pembuatan. Pada halaman ini user dapat mencetak laporan.

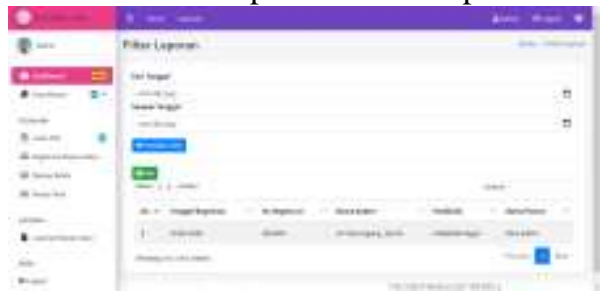

Gambar 9 Form Laporan

4. Pengujian

Pengujian sistem adalah proses untuk menentukan apakah perangkat lunak yang dirancang telah sesuai dengan spesifikasi sistem dan berjalan sesuai yang diinginkan atau tidak (Wibisono \& Susanto, 2015). Pengujian web bertujuan untuk mengetahui bahwa hasil web yang telah dibuat sebagaimana mestinya sesuai dengan yang dirancang dan untuk menghindari kesalahan-kesalahan yang mungkin terjadi. Metode yang dilakukan adalah metode blackbox, yaitu pengujian web berdasarkan fungsi dari web.

a. Pengujian Form Login

Tabel 9 Pengujian Form Login

\begin{tabular}{|c|c|c|c|c|c|}
\hline No & $\begin{array}{c}\text { Skenario } \\
\text { Pengujian }\end{array}$ & $\begin{array}{l}\text { Test } \\
\text { Case }\end{array}$ & $\begin{array}{l}\text { Hasil yang } \\
\text { Diharapkan }\end{array}$ & $\begin{array}{c}\text { Hasil } \\
\text { Pengujian }\end{array}$ & $\begin{array}{c}\text { Kesimp } \\
\text { ulan }\end{array}$ \\
\hline 1 & $\begin{array}{l}\text { Username } \\
\text { dan } \\
\text { password } \\
\text { tidak diisi } \\
\text { kemudian } \\
\text { klik } \\
\text { tombol } \\
\text { login }\end{array}$ & $\begin{array}{l}\text { Userna } \\
\text { me: } \\
\text { (Kosong } \\
\text { ) } \\
\text { Passwor } \\
d \text { : } \\
\text { (Kosong } \\
\text { ) }\end{array}$ & $\begin{array}{l}\text { Sistem akan } \\
\text { menolak dan } \\
\text { akan } \\
\text { menampilkan } \\
\text { pesan "The } \\
\text { Name field is } \\
\text { required" } \\
\text { dan "The } \\
\text { Password } \\
\text { field is } \\
\text { required" }\end{array}$ & $\begin{array}{c}\text { Sesuai } \\
\text { Harapan }\end{array}$ & Valid \\
\hline 2 & $\begin{array}{l}\text { Mengisi } \\
\text { username } \\
\text { tetapi } \\
\text { password } \\
\text { tidak diisi, } \\
\text { lalu klik } \\
\text { tombol } \\
\text { login }\end{array}$ & $\begin{array}{l}\text { Userna } \\
\text { me: } \\
\text { Admin } \\
\text { Passwor } \\
d \text { : } \\
\text { (Kosong } \\
\text { ) }\end{array}$ & $\begin{array}{l}\text { Sistem akan } \\
\text { menolak dan } \\
\text { akan } \\
\text { menampilkan } \\
\text { pesan " The } \\
\text { Password } \\
\text { field is } \\
\text { required" }\end{array}$ & $\begin{array}{c}\text { Sesuai } \\
\text { Harapan }\end{array}$ & Valid \\
\hline 3 & $\begin{array}{l}\text { Mengisi } \\
\text { password } \\
\text { tetapi } \\
\text { username } \\
\text { tidak diisi, } \\
\text { lalu klik } \\
\text { tombol } \\
\text { login }\end{array}$ & $\begin{array}{l}\text { Userna } \\
\text { me: } \\
\text { (Kosong } \\
\text { ) } \\
\text { Passwor } \\
d \text { : } \\
\text { admin }\end{array}$ & $\begin{array}{l}\text { Sistem akan } \\
\text { menolak dan } \\
\text { akan } \\
\text { menampilkan } \\
\text { pesan " The } \\
\text { Name field is } \\
\text { required" }\end{array}$ & $\begin{array}{c}\text { Sesuai } \\
\text { Harapan }\end{array}$ & Valid \\
\hline 4 & $\begin{array}{l}\text { Mengisi } \\
\text { data yang } \\
\text { salah pada } \\
\text { password } \\
\text { kemudian }\end{array}$ & $\begin{array}{l}\text { Userna } \\
\text { me: } \\
\text { admin } \\
\text { Passwor } \\
d:\end{array}$ & $\begin{array}{l}\text { Sistem akan } \\
\text { menolak dan } \\
\text { akan } \\
\text { menampilkan } \\
\text { pesan }\end{array}$ & $\begin{array}{c}\text { Sesuai } \\
\text { Harapan }\end{array}$ & Valid \\
\hline
\end{tabular}




\begin{tabular}{|c|c|c|c|c|c|}
\hline No & $\begin{array}{c}\text { Skenario } \\
\text { Pengujian }\end{array}$ & $\begin{array}{l}\text { Test } \\
\text { Case }\end{array}$ & $\begin{array}{c}\text { Hasil yang } \\
\text { Diharapkan }\end{array}$ & $\begin{array}{c}\text { Hasil } \\
\text { Pengujian }\end{array}$ & $\begin{array}{l}\text { Kesimp } \\
\text { ulan }\end{array}$ \\
\hline & $\begin{array}{l}\text { klik } \\
\text { tombol } \\
\text { login }\end{array}$ & $\begin{array}{l}\text { admin(s } \\
\text { alah) }\end{array}$ & $\begin{array}{l}\text { "Wrong } \\
\text { Password" }\end{array}$ & & \\
\hline 5 & $\begin{array}{l}\text { Mengisi } \\
\text { data yang } \\
\text { salah pada } \\
\text { username } \\
\text { kemudian } \\
\text { klik } \\
\text { tombol } \\
\text { login }\end{array}$ & $\begin{array}{l}\text { Userna } \\
\text { me: } \\
\text { Angga } \\
\text { (salah) } \\
\text { Passwor } \\
\text { d: server }\end{array}$ & $\begin{array}{l}\text { Sistem akan } \\
\text { menolak dan } \\
\text { akan } \\
\text { menampilkan } \\
\text { pesan } \\
\text { "Username is } \\
\text { not } \\
\text { registered" }\end{array}$ & $\begin{array}{c}\text { Sesuai } \\
\text { Harapan }\end{array}$ & Valid \\
\hline 6 & $\begin{array}{l}\text { Mengisi } \\
\text { data yang } \\
\text { benar pada } \\
\text { username } \\
\text { dan } \\
\text { password } \\
\text { kemudian } \\
\text { klik } \\
\text { tombol } \\
\text { login }\end{array}$ & $\begin{array}{l}\text { Userna } \\
\text { me: } \\
\text { admin } \\
\text { Passwor } \\
d \text { : server }\end{array}$ & $\begin{array}{l}\text { Sistem akan } \\
\text { menerima } \\
\text { dan akan } \\
\text { memberikan } \\
\text { akses masuk, } \\
\text { kemudian } \\
\text { diarahkan } \\
\text { pada } \\
\text { dashboard }\end{array}$ & $\begin{array}{c}\text { Sesuai } \\
\text { Harapan }\end{array}$ & Valid \\
\hline
\end{tabular}

b. Pengujian Form User

Tabel 10 Pengujian Form User

\begin{tabular}{|c|c|c|c|c|c|}
\hline No & $\begin{array}{c}\text { Skenario } \\
\text { Pengujian }\end{array}$ & $\begin{array}{l}\text { Test } \\
\text { Case }\end{array}$ & $\begin{array}{c}\text { Hasil yang } \\
\text { Diharapkan }\end{array}$ & $\begin{array}{c}\text { Hasil } \\
\text { Pengujian }\end{array}$ & Kesimpulan \\
\hline 1 & $\begin{array}{l}\text { Klik } \\
\text { tombol } \\
\text { change } \\
\text { password. } \\
\text { Current } \\
\text { Password, } \\
\text { New } \\
\text { Password, } \\
\text { Repeat } \\
\text { Password } \\
\text { tidak diisi } \\
\text { kemudian } \\
\text { klik } \\
\text { tombol } \\
\text { Submit }\end{array}$ & $\begin{array}{l}\text { Curre } \\
n t \\
\text { Passw } \\
\text { ord: } \\
\text { (Koso } \\
\text { ng) } \\
\text { New } \\
\text { Passw } \\
\text { ord: } \\
\text { (Koso } \\
\text { ng) } \\
\text { Repea } \\
t \\
\text { Passw } \\
\text { ord: } \\
\text { (Koso } \\
\text { ng) }\end{array}$ & $\begin{array}{l}\text { Sistem akan } \\
\text { menolak dan } \\
\text { akan } \\
\text { menampilkan } \\
\text { pesan } \\
\text { "Please fill } \\
\text { out this field" }\end{array}$ & $\begin{array}{l}\text { Sesuai } \\
\text { Harapan }\end{array}$ & Valid \\
\hline 2 & $\begin{array}{l}\text { Klik } \\
\text { tombol } \\
\text { change } \\
\text { password, } \\
\text { lalu } \\
\text { mengisi } \\
\text { semua dan } \\
\text { current } \\
\text { password } \\
\text { salah } \\
\text { kemudian } \\
\text { klik } \\
\text { tombol } \\
\text { Submit }\end{array}$ & $\begin{array}{l}\text { Curre } \\
n t \\
\text { Passw } \\
\text { ord: } \\
\text { admin } \\
\text { (salah) } \\
\text { New } \\
\text { Passw } \\
\text { ord: } \\
\text { admin } \\
1234 \\
\text { Repea } \\
t \\
\text { Passw } \\
\text { ord: } \\
\text { admin } \\
\text { 1234 }\end{array}$ & $\begin{array}{l}\text { Sistem akan } \\
\text { menolak dan } \\
\text { akan } \\
\text { menampilkan } \\
\text { pesan } \\
\text { "Wrong } \\
\text { current } \\
\text { password" }\end{array}$ & $\begin{array}{l}\text { Sesuai } \\
\text { Harapan }\end{array}$ & Valid \\
\hline 3 & $\begin{array}{l}\text { Klik } \\
\text { tombol } \\
\text { change } \\
\text { password, } \\
\text { lalu } \\
\text { mengisi } \\
\text { semua } \\
\text { data yang } \\
\text { ada di } \\
\text { field } \\
\text { namun } \\
\text { new } \\
\text { password } \\
\text { dan } \\
\text { repeat } \\
\text { password } \\
\text { salah } \\
\text { kemudian } \\
\text { klik } \\
\text { tombol } \\
\text { submit }\end{array}$ & $\begin{array}{l}\text { Curre } \\
\text { nt } \\
\text { Passw } \\
\text { ord: } \\
\text { server } \\
\text { New } \\
\text { Passw } \\
\text { ord: } \\
\text { admin } \\
1234 \\
\text { Repea } \\
t \\
\text { Passw } \\
\text { ord: } \\
\text { admin } \\
1235\end{array}$ & $\begin{array}{l}\text { Sistem akan } \\
\text { menolak dan } \\
\text { akan } \\
\text { menampilkan } \\
\text { pesan "The } \\
\text { new } \\
\text { password } \\
\text { field does not } \\
\text { match the } \\
\text { confirm new } \\
\text { password } \\
\text { field" }\end{array}$ & $\begin{array}{c}\text { Sesuai } \\
\text { Harapan }\end{array}$ & Valid \\
\hline
\end{tabular}

\begin{tabular}{|c|l|l|l|l|l|}
\hline No & $\begin{array}{l}\text { Skenario } \\
\text { Pengujian }\end{array}$ & $\begin{array}{l}\text { Test } \\
\text { Case }\end{array}$ & $\begin{array}{c}\text { Hasil yang } \\
\text { Diharapkan }\end{array}$ & $\begin{array}{c}\text { Hasil } \\
\text { Pengujian }\end{array}$ & Kesimpulan \\
\hline \multirow{6}{*}{4} & Klik & Curre & & & \\
& nt & & & \\
& tombol & Passw & & & \\
& change & ord: & & & \\
& password, & server & Sistem akan & & \\
& lalu & New & menerima & & \\
& mengisi & Passw & dan & & \\
semua & ord: & menampilkan & Sesuai & Valid \\
& data yang & admin & pesan & Harapan & \\
& ada di & 1234 & "Password & & \\
& field & Repea & has been & & \\
& kemudian & $t$ & changed" & & \\
& klik & Passw & & & \\
& tombol & ord: & & & \\
& Submit & admin & & & \\
& 1234 & & & \\
\hline
\end{tabular}

c. Pengujian Form Registrasi

Tabel 11 Pengujian Form Registrasi

\begin{tabular}{|c|c|c|c|c|c|}
\hline No & $\begin{array}{c}\text { Skenario } \\
\text { Pengujian }\end{array}$ & $\begin{array}{l}\text { Test } \\
\text { Case }\end{array}$ & $\begin{array}{c}\text { Hasil yang } \\
\text { Diharapkan }\end{array}$ & $\begin{array}{c}\text { Hasil } \\
\text { Pengujian }\end{array}$ & $\begin{array}{c}\text { Kesimpul } \\
\text { an }\end{array}$ \\
\hline 1 & $\begin{array}{l}\text { Klik } \\
\text { tombol } \\
\text { input } \\
\text { registrasi. } \\
\text { Nama } \\
\text { Dokter, } \\
\text { Unit } \\
\text { Poliklinik, } \\
\text { Nama } \\
\text { Pasien, } \\
\text { Tanggal } \\
\text { Registrasi } \\
\text { tidak diisi } \\
\text { kemudian } \\
\text { klik } \\
\text { tombol } \\
\text { Submit }\end{array}$ & $\begin{array}{l}\text { Nomor } \\
\text { Registras } \\
\text { i: } \\
\text { (Otomati } \\
\text { s) Nama } \\
\text { Dokter: } \\
\text { (Kosong } \\
\text { ) } \\
\text { Unit } \\
\text { Poliklini } \\
\text { k: } \\
\text { (Kosong } \\
\text { ) Nama } \\
\text { Pasien: } \\
\text { (Kosong } \\
\text { ) } \\
\text { Tanggal } \\
\text { Registras } \\
\text { i: } \\
\text { (Kosong } \\
\text { ) }\end{array}$ & $\begin{array}{l}\text { Sistem akan } \\
\text { menolak dan } \\
\text { akan } \\
\text { menampilkan } \\
\text { pesan } \\
\text { "Please fill } \\
\text { out this field" }\end{array}$ & $\begin{array}{c}\text { Sesuai } \\
\text { Harapan }\end{array}$ & Valid \\
\hline 2 & $\begin{array}{l}\text { Klik } \\
\text { tombol } \\
\text { input } \\
\text { registrasi, } \\
\text { lalu } \\
\text { mengisi } \\
\text { data yang } \\
\text { ada di } \\
\text { field } \\
\text { kemudian } \\
\text { klik } \\
\text { tombol } \\
\text { Submit }\end{array}$ & $\begin{array}{l}\text { Nomor } \\
\text { Registras } \\
\text { i: } \\
\text { REG001 } \\
\text { Nama } \\
\text { Dokter: } \\
\text { Sukirno } \\
\text { Unit } \\
\text { Poliklini } \\
\text { k: } \\
\text { Kandung } \\
\text { an Nama } \\
\text { Pasien: } \\
\text { Susanti } \\
\text { Tanggal } \\
\text { Registras } \\
\text { i: 21-01- } \\
\text { 2020 }\end{array}$ & $\begin{array}{l}\text { Sistem akan } \\
\text { menerima } \\
\text { dan } \\
\text { menampilkan } \\
\text { pesan } \\
\text { "Registrasi } \\
\text { pasien } \\
\text { berhasil di } \\
\text { tambahkan" }\end{array}$ & $\begin{array}{c}\text { Sesuai } \\
\text { Harapan }\end{array}$ & Valid \\
\hline 5 & $\begin{array}{l}\text { Klik } \\
\text { tombol } \\
\text { hapus } \\
\text { pada data } \\
\text { registrasi }\end{array}$ & $\begin{array}{l}\text { Mengha } \\
\text { pus data } \\
\text { registrasi } \\
\text { yang } \\
\text { akan } \\
\text { dihapus }\end{array}$ & $\begin{array}{l}\text { Sistem akan } \\
\text { menerima } \\
\text { dan } \\
\text { menampilkan } \\
\text { pesan } \\
\text { "Registrasi } \\
\text { pasien } \\
\text { berhasil di } \\
\text { hapus" } \\
\end{array}$ & $\begin{array}{c}\text { Sesuai } \\
\text { Harapan }\end{array}$ & Valid \\
\hline 6 & $\begin{array}{l}\text { Klik } \\
\text { kolom } \\
\text { search } \\
\text { dan } \\
\text { ketikkan } \\
\text { kata kunci } \\
\text { untuk } \\
\text { mencari } \\
\text { data } \\
\text { registrasi }\end{array}$ & $\begin{array}{l}\text { Menamp } \\
\text { ilkan } \\
\text { data } \\
\text { registrasi } \\
\text { yang } \\
\text { diingink } \\
\text { an }\end{array}$ & $\begin{array}{l}\text { Sistem akan } \\
\text { menerima } \\
\text { dan } \\
\text { menampilkan } \\
\text { data } \\
\text { registrasi } \\
\text { yang } \\
\text { diinginkan }\end{array}$ & $\begin{array}{c}\text { Sesuai } \\
\text { Harapan }\end{array}$ & Valid \\
\hline
\end{tabular}


d. Pengujian Form Rekam Medis

Tabel 12 Pengujian Form Rekam Medis

\begin{tabular}{|c|c|c|c|c|c|}
\hline No & $\begin{array}{c}\text { Skenario } \\
\text { Pengujian }\end{array}$ & Test Case & $\begin{array}{c}\text { Hasil yang } \\
\text { Diharapkan }\end{array}$ & $\begin{array}{c}\text { Hasil } \\
\text { Penguji } \\
\text { an }\end{array}$ & $\begin{array}{c}\text { Kesimpul } \\
\text { an }\end{array}$ \\
\hline 1 & $\begin{array}{l}\text { Klik } \\
\text { tombol } \\
\text { input } \\
\text { diagnosa. } \\
\text { Tanggal } \\
\text { Periksa, } \\
\text { Nama } \\
\text { Pasien, } \\
\text { Keluhan, } \\
\text { Tensi, } \\
\text { Nama } \\
\text { Dokter, } \\
\text { Diagnosa, } \\
\text { Poliklinik, } \\
\text { Obat tidak } \\
\text { diisi } \\
\text { kemudian } \\
\text { klik } \\
\text { tombol } \\
\text { Submit }\end{array}$ & $\begin{array}{l}\text { Tanggal } \\
\text { Periksa: } \\
\text { (Kosong) } \\
\text { Nama } \\
\text { Pasien: } \\
\text { (Kosong) } \\
\text { Keluhan: } \\
\text { (Kosong) } \\
\text { Tensi: } \\
\text { (Kosong) } \\
\text { Nama } \\
\text { Dokter: } \\
\text { (Kosong) } \\
\text { Diagnosa: } \\
\text { (Kosong) } \\
\text { Poliklinik: } \\
\text { (Kosong) } \\
\text { Obat: } \\
\text { (Kosong) }\end{array}$ & $\begin{array}{l}\text { Sistem akan } \\
\text { menolak dan } \\
\text { akan } \\
\text { menampilkan } \\
\text { pesan } \\
\text { "Please fill } \\
\text { out this field" }\end{array}$ & $\begin{array}{l}\text { Sesuai } \\
\text { Harapan }\end{array}$ & Valid \\
\hline 2 & $\begin{array}{l}\text { Klik } \\
\text { tombol } \\
\text { input } \\
\text { diagnosa, } \\
\text { lalu } \\
\text { mengisi } \\
\text { data yang } \\
\text { ada di field } \\
\text { kemudian } \\
\text { klik } \\
\text { tombol } \\
\text { Submit }\end{array}$ & $\begin{array}{l}\text { Tanggal } \\
\text { Periksa: } \\
03-21- \\
2020 \\
\text { Nama } \\
\text { Pasien: } \\
\text { Susanti } \\
\text { Keluhan: } \\
\text { Lemes } \\
\text { Tensi: } \\
\text { 90/80 } \\
\text { Nama } \\
\text { Dokter: } \\
\text { Sukirno } \\
\text { Diagnosa: } \\
\text { Darah } \\
\text { Rendah } \\
\text { Poliklinik: } \\
\text { Kandunga } \\
\text { n Obat: } \\
\text { Sangobion }\end{array}$ & $\begin{array}{l}\text { Sistem akan } \\
\text { menerima } \\
\text { dan } \\
\text { menampilkan } \\
\text { pesan } \\
\text { "Rekam } \\
\text { medis pasien } \\
\text { berhasil di } \\
\text { tambahkan" }\end{array}$ & $\begin{array}{c}\text { Sesuai } \\
\text { Harapan }\end{array}$ & Valid \\
\hline 5 & $\begin{array}{l}\text { Klik } \\
\text { tombol } \\
\text { hapus pada } \\
\text { data rekam } \\
\text { medis } \\
\text { pasien }\end{array}$ & $\begin{array}{l}\text { Menghapu } \\
\text { s data } \\
\text { rekam } \\
\text { medis } \\
\text { pasien } \\
\text { yang akan } \\
\text { dihapus }\end{array}$ & $\begin{array}{l}\text { Sistem akan } \\
\text { menerima } \\
\text { dan } \\
\text { menampilkan } \\
\text { pesan } \\
\text { "Rekam } \\
\text { medis pasien } \\
\text { berhasil di } \\
\text { hapus" }\end{array}$ & $\begin{array}{c}\text { Sesuai } \\
\text { Harapan }\end{array}$ & Valid \\
\hline 6 & $\begin{array}{l}\text { Klik } \\
\text { kolom } \\
\text { search dan } \\
\text { ketikkan } \\
\text { kata kunci } \\
\text { untuk } \\
\text { mencari } \\
\text { data rekam } \\
\text { medis } \\
\text { pasien }\end{array}$ & $\begin{array}{l}\text { Menampil } \\
\text { kan data } \\
\text { rekam } \\
\text { medis } \\
\text { pasien } \\
\text { yang } \\
\text { diinginkan }\end{array}$ & $\begin{array}{l}\text { Sistem akan } \\
\text { menerima } \\
\text { dan } \\
\text { menampilkan } \\
\text { data rekam } \\
\text { medis pasien } \\
\text { yang } \\
\text { diinginkan }\end{array}$ & $\begin{array}{c}\text { Sesuai } \\
\text { Harapan }\end{array}$ & Valid \\
\hline
\end{tabular}

e. Pengujian Form Laporan

Tabel 12 Pengujian Form Laporan

\begin{tabular}{|c|l|l|l|c|c|}
\hline No & $\begin{array}{c}\text { Skenario } \\
\text { Pengujian }\end{array}$ & \multicolumn{1}{|c|}{$\begin{array}{c}\text { Test } \\
\text { Case }\end{array}$} & $\begin{array}{c}\text { Hasil yang } \\
\text { Diharapkan }\end{array}$ & $\begin{array}{c}\text { Hasil } \\
\text { Penguji } \\
\text { an }\end{array}$ & $\begin{array}{c}\text { Kesimp } \\
\text { ulan }\end{array}$ \\
\hline \multirow{2}{*}{1} & $\begin{array}{l}\text { Tanggal } \\
\text { kosong dan } \\
\text { klik tombol } \\
\text { Tampilkan } \\
\text { Data }\end{array}$ & $\begin{array}{l}\text { Dari: } \\
\text { hh/bb/ttt } \\
\text { Sampai: } \\
\text { hh/bb/ttt }\end{array}$ & $\begin{array}{l}\text { Sistem akan } \\
\text { menolak dan } \\
\text { menampilkan } \\
\text { pesan } \\
\text { "Please fill } \\
\text { out this field" }\end{array}$ & $\begin{array}{c}\text { Sesuai } \\
\text { Harapan }\end{array}$ & Valid \\
\hline \multirow{2}{*}{2} & $\begin{array}{l}\text { Isi salah satu } \\
\text { kolom } \\
\text { tanggal dan } \\
\text { klik tombol } \\
\text { tampilkan } \\
\text { data }\end{array}$ & $\begin{array}{l}\text { Dari: } \\
17-06- \\
2020 \\
\text { Sampai: } \\
\text { hh/bb/ttt }\end{array}$ & $\begin{array}{l}\text { Sistem akan } \\
\text { menolak dan } \\
\text { menampilkan } \\
\text { pesan } \\
\text { "Please fill } \\
\text { out this field" }\end{array}$ & Sesuai & Harapan \\
\hline 3 & Isi semua & Dari: & Sistem akan & Sesuai & Valid \\
\hline
\end{tabular}

\begin{tabular}{|c|c|c|c|c|c|}
\hline No & $\begin{array}{l}\text { Skenario } \\
\text { Pengujian }\end{array}$ & $\begin{array}{l}\text { Test } \\
\text { Case }\end{array}$ & $\begin{array}{l}\text { Hasil yang } \\
\text { Diharapkan }\end{array}$ & $\begin{array}{c}\text { Hasil } \\
\text { Penguji } \\
\text { an }\end{array}$ & $\begin{array}{c}\text { Kesimp } \\
\text { ulan }\end{array}$ \\
\hline & $\begin{array}{l}\text { kolom } \\
\text { tanggal dan } \\
\text { klik tombol } \\
\text { tampilkan } \\
\text { data }\end{array}$ & $\begin{array}{l}17-06- \\
2020 \\
\text { Sampai: } \\
20-06- \\
2020\end{array}$ & $\begin{array}{l}\text { menerima } \\
\text { dan akan } \\
\text { menampilkan } \\
\text { data laporan } \\
\text { yang sesuai } \\
\text { dengan } \\
\text { tanggal yang } \\
\text { diinginkan }\end{array}$ & Harapan & \\
\hline 4 & $\begin{array}{l}\text { Klik tombol } \\
\text { Print }\end{array}$ & $\begin{array}{l}\text { Menam } \\
\text { pilkan } \\
\text { data } \\
\text { laporan } \\
\text { yang } \\
\text { akan } \\
\text { dicetak }\end{array}$ & $\begin{array}{l}\text { Sistem akan } \\
\text { menerima } \\
\text { dan } \\
\text { menampilkan } \\
\text { data laporan } \\
\text { dan pop-up } \\
\text { cetak }\end{array}$ & $\begin{array}{c}\text { Sesuai } \\
\text { Harapan }\end{array}$ & Valid \\
\hline
\end{tabular}

\section{Support}

Suatu program tidak akan dapat digunakan jika tidak didukung dari perangkat keras (hardware) dan perangkat lunak (software). Hardware dan software dibutuhkan dalam konfigurasi sistem komputer agar dapat melakukan pekerjaan komputerisasi. Berikut spesifikasi yang dibutuhkan:

a. Spesifikasi Perangkat Keras (Hardware)

Server

1) $C P U$
a) Processor : Intel Core i3-6006U
b) Memory : 16 GB DDR4
c) Hard disk : $500 \mathrm{~GB}$

2) Mouse

3) Keyboard

4) Monitor dengan resolusi layar 1366 x 768

5) Koneksi internet dengan kecepatan $9 \mathrm{Mbps}$

Client

1) $\mathrm{CPU}$
a) Processor : Intel Core i3-6006U
b) Memory : 16 GB DDR4
c) Hard disk : $500 \mathrm{~GB}$

2) Mouse

3) Keyboard

4) Monitor dengan resolusi layar $1366 \times 768$

5) Koneksi internet dengan kecepatan $9 \mathrm{Mbps}$

b. Spesifikasi Perangkat Lunak (Software) Server

a) Sistem operasi : Microsoft Windows 10

b) Aplikasi bundle web server : XAMPP versi 3.2.4

c) Aplikasi web browser Google Chrome

Client

a) Sistem operasi : Microsoft Windows 10

b) Aplikasi bundle web server : XAMPP versi 3.2.4

c) Aplikasi web browser : Google Chrome 


\section{KESIMPULAN}

Berdasarkan hasil pembahasan dari Perancangan Program Administrasi Rawat Jalan Rumah Sakit Ibu dan Anak Ibnu Sina dapat disimpulkan :

1. Mampu mempermudah dan mempercepat tugas user dan dokter dalam proses pengelolaan data pasien, data rekam medis dan laporan data.

2. Aplikasi ini juga mengurangi penggunaan kertas dalam penyimpanan data karena sudah tergantikan dengan menggunakan database sehingga data tidak mudah rusak dan hilang.

3. Mempermudah dalam proses pencarian datadata yang diperlukan.

4. Pasien tidak perlu membawa kertas resep untuk dibawa kebagian administrasi karena data resep sudah terkirim kebagian administrasi

\section{REFERENSI}

Dermawan, J., \& Hartini, S. (2017). Implementasi Model Waterfall Pada Pengembangan Berbasis Web Pada Sekolah Dasar Al-Azhar Syifa Budi Jatibening. Paradigma, 19(2), 142147.

F, L. A., Latif, A., Mustopa, A., \& Fachrurozi, A. (2019). Sistem Informasi Rekam Medis Berbasis Web Pada Puskesmas Rasau Jaya Pontianak Menggunakan Framework Laravel 5 . 6. Infortech, 1(2), 92-96.

Fridayanthie, E. W., \& Mahdiati, T. (2016). Rancang Bangun Sistem Informasi Permintaan ATK Berbasis Intranet (Studi Kasus: Kejaksanaan Negeri Rangkasbitung). Jurnal Khatulistiwa Informatika, 4(2), 132.

Handayani, V. R., Suripah, S., Ika, A., \& Putri, R. (2020). Sistem Informasi Administrasi Pasien Rawat Jalan Berbasis Website Pada Klinik Pratama Menara Gading Wangon. 8(1).

Hardiyanto, Abdussomad, Haryadi, E., Sopandi, R., \& Asep. (2019). Penerapan Model Waterfall Dan UML Dalam Rancang Bangun Program Pembelian Barangberorientasi Objek Pada PT. Fujita Indonesia. Interkom, 13(4), 6.

Muharam, A., Yuliandari, D., \& Sutanto, G. D. (2018). Perancanagn Sistem Pembelian
Material Berorientasi Objek Pada PT HI-Tech Ink Indonesia Cikarang. Jurnal Inkofar, 1(1), $110-117$.

Wibisono, G., \& Susanto, W. E. (2015). Perancangan Website Sebagai Media Informasi dan Promosi Batik Khas Kabupaten Kulonprogo. 3(2), 64-69.

Dermawan, J., \& Hartini, S. (2017). Implementasi Model Waterfall Pada Pengembangan Berbasis Web Pada Sekolah Dasar Al-Azhar Syifa Budi Jatibening. Paradigma, 19(2), 142147.

F, L. A., Latif, A., Mustopa, A., \& Fachrurozi, A. (2019). Sistem Informasi Rekam Medis Berbasis Web Pada Puskesmas Rasau Jaya Pontianak Menggunakan Framework Laravel 5 . 6. Infortech, 1(2), 92-96.

Fridayanthie, E. W., \& Mahdiati, T. (2016). Rancang Bangun Sistem Informasi Permintaan ATK Berbasis Intranet (Studi Kasus: Kejaksanaan Negeri Rangkasbitung). Jurnal Khatulistiwa Informatika, 4(2), 132.

Handayani, V. R., Suripah, S., Ika, A., \& Putri, R. (2020). Sistem Informasi Administrasi Pasien Rawat Jalan Berbasis Website Pada Klinik Pratama Menara Gading Wangon. 8(1).

Hardiyanto, Abdussomad, Haryadi, E., Sopandi, R., \& Asep. (2019). Penerapan Model Waterfall Dan UML Dalam Rancang Bangun Program Pembelian Barangberorientasi Objek Pada PT. Fujita Indonesia. Interkom, 13(4), 6.

Muharam, A., Yuliandari, D., \& Sutanto, G. D. (2018). Perancanagn Sistem Pembelian Material Berorientasi Objek Pada PT HI-Tech Ink Indonesia Cikarang. Jurnal Inkofar, 1(1), $110-117$.

Wibisono, G., \& Susanto, W. E. (2015). Perancangan Website Sebagai Media Informasi dan Promosi Batik Khas Kabupaten Kulonprogo. 3(2), 64-69. 